\title{
The Democratic Republic of Congo: Endeavoring Women Empowerment after a War of Rape
}

\author{
Deni Meutia \\ International Relations Department, Universitas Respati Yogyakarta - Indonesia \\ Email: denimeutia@yahoo.com \\ Submitted: 21 April 2018 | Accepted: 17 Mei 2018
}

\begin{abstract}
This paper analyzed the use of rape as a weapon in Democratic Republic of Congo conflict zone. Rape usually used by the arm group to weaken their enemy. This strategy did not only targeted to women but also men. Rape gave different effect toward women and men. The purpose of this paper is to explain how rape become the weapon of conflict and their effect to the victims, even men and woman. Feminist perspective used in this paper. In the end, the author found that women have a way to overcome the effect and impact of rape better than men do. Social structure, which placed men in the upper side of women, made the effect and impact on the men who experienced rape victim hard to release their suffering. Therefore, the main goal of this paper is to show how women and men could manage their self as a victim in the conflict zone.
\end{abstract}

Keywords: Women, Men, Rape, Conflict, Weapon, War.

\section{Abstrak}

Dalam penelitian ini dianalisis tentang aksi pemerkosaan yang terjadi di Republik Demokratik Kongo sebagai senjata oleh kelompok bersenjata untuk melemahkan musuh. Praktiknya, aksi pemerkosaan digunakan oleh kelompok bersenjata sebagai upaya untuk melemahkan lawan. Strategi ini tak hanya berfokus pada wanita sebagai targetnya namun juga kepada laki-laki. Dalam penelitian ini digunakan perspektif feminisme. Struktur sosial yang berada dalam diri laki-laki membuatnya sulit untuk melupakan efek dan dampak dari aksi pemerkosaan apabila menjadi korban dibandingkan dengan perempuan. Tujuan besar dari penelitian ini adalah untuk menunjukkan bagaimana perempuan dan laki-laki mampu untuk mengelola dirinya sebagai korban perang dan pemerkosaan dalam wilayah konflik.

Kata Kunci: Perempuan, Laki-laki, Pemerkosaan, Konflik, Senjata, Perang.

\section{INTRODUCTION}

The Democratic Republic of Congo (DRC), formerly named as Zaire, is a nation located in Central Africa with its population about 70 million. The Second Congo War, beginning in 1998, devastated the country, involved seven foreign armies and sometimes referred to as the
"African World War". Despite the signing of peace accords in 2003, fighting continues in the east of the country. In eastern Congo, the prevalence of rape and other sexual violence described as the worst in the world, the war is the world's deadliest conflict since World War II, killing 5.4 
million people (Carayannis and Weiss, 2003). DRC are among the poorest country in the world, which is the second poorest country in the world, ahead of Zimbabwe.

The conflict in DRC was the effect of Rwandan Civil War and Rwandan Genocide. The Rwanda Hutu Military force called Interahamwe had fled of Rwanda to avoid aggression from Tutsi-Rwanda Government and build a camp in eastern Zaire (the former name of DRC). Then Hutu-Rwanda militia force allied with Zaire armed force (FAZ) launched campaign against Tutsi ethnics in Eastern Zaire. This alliance, led by Laurent-Désiré Kabila, might continue to the rebellion of Mobutu government who controlled DRC for along more than 2 decades. In May 1997 finally Mobutu fled the Zaire and Kabila remained become the president and changed the country name to Democratic Republic of Congo.

After becoming the President of DRC, Kabila wanted to Rwandan military force to back to their country but it was not accepted from the militia. The Rwandan militia moved to Goma and launched the militia rebellion group against Kabila government. More rebellion group had also up; they named the group as Movement the Liberation for Congo (MLC). The rebel movement started second civil war against DRC army, backed up by Rwanda and Uganda troop, in 1998 (Carayannis and Weiss, 2003).

In 2001, Kabila assassinated and then succeeded by his son Joseph Kabila who called international intervention to end the war in Congo. In February 2001 had a peace deal between Kabila, Rwanda and Uganda to withdrawn their troop army, soon after the UN peacekeeping military MONUC came to Congo (Cayannis and Weiss, 2003). However, the conflict become worse with raised the impact that Rwanda and Uganda pending the withdrawal of the troop otherwise they sent more troo The conflict did not only destroy Congo but also affected the neighboring 
country such as in borderline between Congo-Rwanda and Congo-Uganda.

The war was the world's deathly conflict after the Second World War. The conflict remains a destructive effect for the people of Congo especially toward women and children. They become the vulnerable groups who have to be helped to gain the high standard of living.

\section{DISCUSSION}

\section{Men in Conflict "the Genocide upon Rich- Mineral Land and Humiliation"}

Even many men are the combatant and soldier army but some of men who had suffered from the conflict. Genocide, which addressed to ethnic minorities in Congo, has killed many men. This genocide became wider caused of the security of richmineral land that owned by some ethnic group, since the land ownership right belong to men so the men in that areas become the target of murder. To save their life, the men fled their land. According to Human Rights Watch, men also become the victim of sexual violence (Human Right Watch: An Interview, 2010):

"On October 19, 2001, armed FDD combatants raped two children in a village near Baraka on Lake Tanganyike. A mother, Agnès T., told Human Rights Watch researchers that the assailants raped her thirteen-year-old daughter and her sixteen-year-old son in front of her. FDD rebels had attacked a group of anglers, including her son. They tied them up and later that night brought the tiedup boy to her home in search of money. Agnès T.'s husband managed to escape through a window but the assailants caught her and tied her u Four rebels raped her daughter. They also raped her son, "like a girl," said Agnès. T. Then the combatants looted the house and left. Both children suffered infections as a result, and the girl spent a month in the bospital".

According to Oxfam, Human Rights Watch, United Nations officials and several Congolese aid organizations, the number of men had been raped has risen sharply, a consequence of joint Congo-Rwanda military operations against rebels that have uncapped an appalling level of violence against civilians. Aid workers struggle to explain the sudden spike in male rape cases. The best answer, they say, is that the sexual violence against men is yet another way for armed 
groups to humiliate and demoralize

Congolese communities into submission.

What the man has than woman has in the conflict is they have freedom. They can freely leave their wife or children without worrying because the responsible to take care of children and elderly belong to women. The man also took decision to join either militia rebel group or government army look for safety. Male household heads often settle violent crimes against women and girls outside the courts. Some have "resolved" rape cases by accepting a money payment from the perpetrator or his family or by arranging to have the perpetrator marry the victim.

\section{Women in Conflict: Sexual Violence as a Weapon of War}

Women become the most vulnerable group causing by the conflict in Congo. Many women suffered from the effect of the conflict. When conflict occurred, women have been the target of war. The use of sexual weapon became the dangerous means to dehumanize people and cheap weapon of fearing. Sexual violence as rape became the weapon in addition to ensure that communities accept the power and authority of that particular armed group neither nor the soldier bored and having nothing to do. It is about showing teror and a weapon of war (CBS News Report, 2008). Rape is like a norm in Congo. Many women and girls suffered from it every day with a new victim in each day.

In some cases soldiers and combatants raped women and girls as part of a more general attack in which they killed and injured civilians and pillaged and destroyed their property. They did this to terorize communities into accepting their control or to punish them for real or supposed aid to opposing forces, particularly if their have been recently attacked by these forces. In cases where there was no larger attack, individuals or small groups of soldiers and combatants also raped women and girls whom they found in the fields, in the forest, along the roads, or in their homes (The 
Aftermath of Rape and other Forms of Sexual Violence, 2010).

The war, which has ravaged this region intermittently since 1996, has destroyed the local economy. Driven by desperate poverty, women who provided the resources to keep their families alive continued going to the fields to cultivate, to the forest to make charcoal, or to markets to trade their goods even though doing so put them at risk of sexual violence (The Aftermath of Rape and Other Forms of Sexual Violence, 2010). Soldiers and combatants preyed upon such women and girls as well as on others who had fled combat to live in temporary and fragile structures in the forest. In many cases, combatants abducted women and girls and took them to their bases in the forest where they forced them to provide sexual services and domestic labor, sometimes for periods of more than a year. Among the hundreds of thousands displaced by the war were many women who sought safety for themselves and their families in towns. Some rapists aggravated their crimes by other acts of extraordinary brutality, shooting victims in the vagina or mutilating them with knives or razor blades. Some attacked girls as young as five years of age or elderly women as old as eighty. Some killed their victims outright while others left them to die of their injuries. However, rape and other sexual crimes not just carried out by armed factions but also police and others in positions of authority and power, and by opportunistic common criminals and bandits, taking advantage of the prevailing climate of impunity and the culture of violence against women and girls (The Aftermath of Rape and Other Forms of Sexual Violence, 2010). Irregular combatants and regular soldiers responsible for acts of sexual violence commit war crimes. In some cases, their crimes could amount to crimes against humanity.

Rape as weapon of war considered as an instrument to take power rather than sexual activity (Mullins, 2009, 49). The victim of rape who was largely women come from gendered power dynamics. Subordination of women in society 
made them weak and unsecure. In the conflict zone, it became worse because of the lack economy infrastructure. Otherwise, women was being the only one family member who had to take care of them. Even in the wartime, women still going to the fields to cultivate, to the forest to make charcoal, or to markets to trade their goods even though doing so puts them at risk of sexual violence. Conflict creates desperate conditions where men rape women to sustain themselves to continue fighting (Brown, 2012, 29). in very simple way we can assume that rape is not so much about sex but the power of men to survive in another day. It related to patriarchy which putting women inferior to men in society. Taken together, the cultural and structural research on rape establishes that within a civilian context, sexual assault is organized and regulated within a social order, as it reinforces male beliefs about sexual privilege and access (Mullins, 2009, 25).

\section{The Gender Perspective: How Men and Women Get Difference Experience to Relief the Effect of Conflict?}

Feminist theory takes into account the gender inequality and gender roles that could be used to explaining the provocation and use of rape. The absolute status of women together with gender equality is highly influential in the presence of rape in a society. In addition, it emphasize "the unique role of women as a class within the economic structure". In other words, a woman's status, both socially and economically, plays a significant role in their victimization of rape (Klein in Brown, 2012, 321). Congo's male patriarchy created a culture for men to exploit and abuse women. Rape became an instrument to justify male domination and power spread fear for managing their status in gender stratification system. In wartime, rape used by the combatant to overpower women and placed them in submission. Women became an object of men brutality because of a long conflict frustration. 
Women and girls of eastern Congo, their families, and the larger community have developed different strategies to protect them from sexual violence. Some families have sent their women and girls to safer locations. Another frequently used strategy is seeking safety in numbers. When possible, women and girls try to go to market, to the forest, or to the fields in groups; hoping that can discourage assailants. Sometimes effective, this practice at other times just delivers larger numbers of women and girls into the hands of assailants. In a variant of this strategy, older women, thought to be less vulnerable to attack, have replaced young women and girls in carrying out activities that require traveling some distance from home. Useful in protecting those who might otherwise be most targeted, this strategy provides no protection for the older women. In towns, some women and girls now wear an extra layer of clothes known as umugondo or just gondo to make it more difficult for assailants to get at their bodies (The War within The War; by Human Right
Report, 2010). If confronted by armed men who intended to rape them, some women and girls have fought back, using their wits as well as their fists and feet. Some have tried to shame or persuade their assailants to leave them alone while others have resisted physically or fled. Given the disproportionate power in the hands of the assailants, relatively few women and girls succeeded in escaping rape and other injuries.

Now some of the women are fighting back the only way they know how - by talking about what happened. A campaign spearheaded by the U.N. Children's Fund is working with local groups to break traditional taboos around talking about the violence. They are using radio stations broadcasting in local languages, and more activists are getting to remote areas.

"Many more victims are coming forward. $W$ e receive a lot of SMS text messages and cell phone calls from women who have been raped and need help," says campaign leader Esther Ntoto (Faul, 2009).

The UN officials began bringing together women to tell their stories to 
rooms full of local officials, community leaders, even children. One sign of success is that more men than women have volunteered for training to encourage victims to come forward and their communities to confront the issues. Video footage of the campaign Women Breaking the Silence shows officials startled by the atrocities recounted. A provincial minister interrupted to ask reporters not to film a woman's face. However, she took the microphone to declare:

"I am not ashamed to show my face and publish my identity. The shame lies with those who broke me open and with the authorities who failed to protect me. If you don't hear me, see me, you will not understand why it is so important that we fight this together" (Human Right Watch, 2010).

That woman, Honorata Kizende, described how her life as a schoolteacher and the mother of seven children ended when she has kidnapped in 2001. She has held as a sex slave for 18 months and passed around from one Hutu fighter to another until she escaped. She is now a counselor and trains others to help survivors of sexual violence (The New York Times, 2009).

In other side, men are differently facing up their trauma. They have no courage to release their pain in front of public society that is why men are likely suffering so deep in sexual abuses. However, nobody knows the exact number. Men here, like anywhere, are reluctant to come forward. Several who did said they instantly became castaways in their villages, lonely, ridiculed figures, derisively referred to as "bush wives". (The New York Times, 2009). The male rape cases are still just a fraction of those against women. However, for the men involved, aid workers say, it is even harder to bounce back. In addition, in a place where homosexuality is so taboo, the rapes carry an extra dose of shame. The humiliation is often so severe that male rape victims come forward only if they have urgent health problems, like stomach swelling or continuous bleeding. Sometimes even that is not enough. In some case, there are two men penises were cinched with rope 
died a few days later because they were too embarrassed to seek hel Castrations also seem to be increasing, with more butchered men showing up at major hospitals.

Women and men are differently facing up the pain caused of rape. When women suffered the pain caused of rape, they can easily release from the trauma by sharing out with another woman or people who care to them. This is the nature of women. Nevertheless, men have different manner in facing up their trauma. Sharing out the bad experience is something embarrassing for men. Men are the symbol of power and dignity in Congo, when they got some of shameful experience it made them powerless and did not have their privilege anymore that is why it is difficult toward men to recover from rape experience. Therefore, the greatest silence among the victims of sexual abuse exactly happened to men, because they do not have courage to face society about what they had experienced.

\section{Building Peace in the Democratic Republic of Congo}

How to make peace in Congo sustainable for every people in that country? Need many efforts to make it true, men and women have to be involved in peace building process. Peace building cannot success if half the population excluded from the process. That is the reason why women have to be involved to build peace because they are the victims of the conflict, they know what should to be the best to them. The decision making of peace building process dominated by men in every place of conflict, but they don't experience what the women and children feel about the conflict so the result of peace building programs seem to be masculine project. It is about changing gender norms to make peace in Democratic Republic of Congo. In the men's mind, attack to the one person is the attack to the whole community. Therefore, it is difficult how to change his or her belief and try to give understanding that it is about 
humiliation and every people should have rescued.

Rape has numerous consequences, including physical injury, psychosocial trauma, unwanted pregnancies, fistulae and HIV/AIDS infection. The lack of capacity in terms of medical personnel and basic equipment are impediments to fully taking into account the needs of victims who often live in remote and inaccessible areas. In order to respond to the victim' immediate needs, health structures must be available and equipped and health personnel trained properly. Sexual and gender-based violence prevention and response demand that the health system restored. This will contribute significantly to peacebuilding nationwide. Peace could not be achieved without peace in the hearts and souls of the victims of sexual and gender-based violence. Mental and emotional healing blazes a trail for forgiveness, a prerequisite for peace. The fight against poverty and economic exclusion also facilitates peacebuilding. The lack of security and protection of civilians is conducive to an environment where perpetrators not denounced for fear of reprisal. As a result, thousands of victims do not seek justice and suffer from psychological and physical injuries in silence. This attitude, which stems from fear and disenchantment vis-avis the judicial system, hinders national reconciliation, peacebuilding and development efforts in the country. The understanding of gender perspective will enable them to better fulfil their role as protectors of vulnerable groups (UNDP and UNFPA report, 2010).

Reaffirming the role of women in preventing and resolving conflicts, it called for increasing their decisionmaking participation in all institutions dealing with conflict. Women remain marginalized in formal peace processes and post-conflict governments. Although the stereotype of "women as only victims" should not reinforced, the scale of discrimination and violence against women in each armed conflict remains the central obstacle to expanding the good work being done 
by women peacebuilders. Because those who are courageous and capable enough to involve themselves as catalysts in peacebuilding are an endangered minority, they should become safe guarded and strengthened with funding, training and inclusion in decision-making mechanisms that shape fundamental questions of security and development.

Their organizations identified at the outset of peacemaking processes and helped to work within broader peace initiatives and to communicate their messages to both national leaders and the international community. Women make a difference in part because they often adopt a more inclusive approach toward security and address key social and economic issues that would otherwise be ignored. (UNDP and UNFPA report, 2010).

\section{CONCLUSION}

The Congo conflict became the worse conflict in the world as the used of sexual violence as a weapon of war. Not only women who become the victims but also men. However, there is different way in facing the pain between men and women. According to the men, when they committed the sexual violence it would be so embarrassing for them, because the patriarchal system who believe that men are symbol of power. Being abuse, for men, made them as the subordinate civilian just like women.

There is a famous call toward men have been abused as "bush-wife". Become the "bush-wife" made a man no longer a man any more; he lost his dignity as a man. That is why the male rape victim rarely found because of they too feared to speak out.

Even society believe that the greatest silence - fact that a lot of women who have been raped, but did not want to speak about - come for women but women still have their courage in facing up their pain and move their life. Women in social system in Congo are responsible for caring children and any household job. As long as the men disappeared, the women become the backbone of family this is provide them a power to 
continue their life. Women found their way to release from such emotional trauma by sharing their experienced with other victims and make abound to help the rape victims to face up their life.

Even though women have a capability to become the peace builder but there still a low awareness to involve women in peace building project. Any decision making do not involving women in so that what will happen are any project made by decision maker do not touch the main cause of the problem. It should be more women participation in the peace-building project, because they know what should be do. In the conflict like Congo, there is need strong effort changing gender norm to make peace in that place remains sustainable.

\section{REFERENCE}

Amnesty International. (2004) DRC: Mass Rape - Time for Remedies (Online). https://www.amnesty.org/en/docum ent s/afr62/018/2004/en/ (Accessed: 13 December 2010).

Brown, Carly. (2012) "Rape as Weapon of War in The Democratic Republic of Congo", Torture, Vol. 22 Number 1,
Carayannis, T. and Weiss, H. (2003) The Democratic Republic of Congo, 19962002, in Boulden, J. (ed) Dealing with conflict in Africa: The United Nations and Regional Organizations. Basingstoke: Palgrave MacMillan.

CBS News Report. (2008) War against Woman, the Use of Rape As a Weapon in Congo's Civil War (Online). Available at: https://www.cbsnews.com/news/war - against-women/ (Accessed:

December 09, 2010).

Faul, Michelle. (2009) Congo Women Fight Back, Speak out about Rape (Online). Available at: http://www.nbcnews.com/id/297192 77/ns/world_news-africa/t/congowomen-fight-back-speak-out-aboutrape/\#.WxIkKIoxXDc (Accessed: December 13, 2010).

Human Right Watch. (t.t) An Interview (Online). Available at: http://www.hrw.org/reports98/publc tns.html (Accessed: December 09, 2010).

Human Rights Watch. (2002) The War within War: Sexual Violence against Woman and Girls in Eastern Congo. New York: Human Rights Watch, pp. 27- 37.

International Crisis Group. (2009) Congo: Five Priorities for a Peacebuilding Strategy (Online). Available at: https://www.crisisgrouorg/africa/cen tra l-africa/democratic-republiccongo/congo-five-prioritiespeacebuilding-strategy (Accessed: May 2010).

Mullins C. (2009) "We Are Going To Rape You And Taste Tutsi Women: Rape During The 1994 Rwandan Genocide", The British Journal of Criminology, Volume 49, Issue 6, 1 November 2009, pp. 19-735.

UNDP and UNFPA Report. (2010) Postconflict Peacebuilding in Africa: the Role of UNDP and UNFP $A$ in the Democratic 
Republic of the Congo (Online). Available at:

web.undorg/execbrd/word/DRC $\% 2$ 0Backgrou nd $\% 20$ Note.doc

(Accessed: May 2011). 